\title{
The effect of fabric on the behaviour of gold tailings
}

\author{
N. $\mathrm{CHANG}^{*}, \mathrm{G} \cdot \mathrm{HEYMANN} \dagger$ and C. CLAYTON\$
}

Undisturbed sampling of gold tailings, especially under the water table, is difficult and in many cases impossible. For this reason laboratory testing of tailings is generally conducted on reconstituted material. It has been shown that laboratory sample preparation methods can affect the mechanical behaviour of cohesionless soil and it is generally believed that the difference in mechanical behaviour is attributable to a difference in the fabric (particle arrangement) inherent in the preparation method. An experimental programme was conducted to (a) examine the fabric which ensues upon sample preparation and $(b)$ to investigate the effect of any fabric differences on the mechanical behaviour of gold tailings. Comparison was made between the behaviour and fabric of undisturbed and reconstituted moist tamped and slurry deposited samples. The results from the experimental programme show that there is indeed a difference in fabric between undisturbed and reconstituted gold tailings samples. Slurry preparation generally replicates the fabric and behaviour of the undisturbed sample better than moist tamping, but neither fully replicates the undisturbed sample. At large strains, the samples reach a unique critical state friction angle, but at different stress states.

KEYWORDS: fabric/structure of soils; laboratory tests; liquefaction; microscopy; shear strength; silts; stiffness; stress path
L'échantillonnage intact de stériles d'or, notamment sous la nappe phréatique, est difficile, parfois même impossible. C'est pour cette raison que les essais sur des stériles, qui se déroulent en laboratoire, s'effectuent généralement sur des matières reconstituées. On a démontré que des méthodes de préparation en laboratoire des échantillons risquent d'affecter le comportement mécanique de sols sans cohésion, et on estime généralement que la différence de comportement mécanique est attribuable à la différence de disposition particulaire inhérente à la méthode de préparation. On a effectué un programme expérimental pour (1) examiner la disposition particulaire faisant suite à la préparation de l'échantillon et (2) rechercher l'effet de différences de la disposition particulaire sur le comportement mécanique de stériles d'or. On a effectué une comparaison entre le comportement et la disposition particulaire d'échantillons intacts et reconstitués pilonnés à l'état humide et déposés par boues. Les résultats de ce programme expérimental indiquent qu'il existe bel et bien une différence, sur le plan de la disposition particulaire, entre les échantillons de stériles d'or intacts et reconstitués. En général, la préparation des boues reproduit la disposition particulaire et le comportement de l'échantillon intact beaucoup mieux que le pilonnage humide, mais aucun des deux ne reproduit de façon intégrale l'échantillon intact. Avec des contraintes élevées, les échantillons atteignent un angle de frottement unique à l'état critique, mais avec des tensions différentes.

\section{INTRODUCTION}

Electron microscopy technology allows observation of soil particles making it possible to study the effect of fabric and structure on soil behaviour. The terms 'fabric' and 'structure' have often been used interchangeably to describe soil particle and aggregate arrangement. In the context of this paper, however, the definition of Lambe \& Whitman (1969) and Mitchell (1976) has been adopted. 'Fabric' defines the arrangement of particles of all size ranges, shapes and associated pores while 'structure' defines the combination of fabric and bonding (inter-particular forces, including cementation, electrostatic, electromagnetic or any other force which keeps the particles together).

The behaviour of gold tailings is generally estimated from laboratory tests on disturbed material owing to the difficulty of obtaining undisturbed samples during the operational life of a tailings dam. Laboratory reconstituted samples, however, may not replicate the behaviour of the in-situ deposit fully. In the past few decades, researchers such as Oda (1972), Ladd (1974), Mulilis et al. (1977), Kuerbis \& Vaid (1988), Vaid et al. (1990), Ishihara (1993), Zlatovic \& Ishihara (1997), Chillarige et al. (1997), Dyvik \& Høeg

Manuscript received 19 May 2009; revised manuscript accepted 20 January 2010. Published online ahead of print 26 July 2010.

Discussion on this paper closes on 1 August 2011, for further details see p. ii.

* Franki Africa (Pty) Ltd, Gauteng, South Africa.

$\uparrow$ University of Pretoria, South Africa.

$\ddagger$ University of Southampton, UK.
(1999) and Vaid et al. (1999) have shown that the behaviour of non-plastic, cohesionless soil samples produced using different reconstitution methods may be significantly different. Mulilis et al. (1977) investigated the liquefaction characteristics of saturated sand and concluded that the compaction procedures significantly affect the liquefaction characteristics of the sand. Electrical conductivity measurements also showed that samples prepared using different methods exhibit different conductivity factors (Mulilis et al., 1977). Zlatovic \& Ishihara (1997) presented results on undrained triaxial results on loose silty sands and concluded that the shear response of sands depends significantly on the preparation method. Similar results have been presented by Dyvik \& Høeg (1999), Vaid et al. (1999), Vaid \& Sivathayalan (2000) and Høeg et al. (2000). Wood (1999) presented undrained triaxial results on sand-silt mixes prepared using various preparation methods and, with the aid of scanning electron micrograph (SEM) images, concluded that the difference in shear response can be related to a difference in the number of stable and unstable particle contacts. According to Yamamuro \& Lade (1997), the stability of silty sand is generated by direct contact between sand particles and instability is produced by load-bearing silt particles between sand grains.

Previous work focused on the static liquefaction behaviour of sands or silty sands and it is unclear whether similar effects occur in gold tailings, which are generally classified as silt or sandy silt with platy fines (Vermeulen, 2001). The objectives of this study were $(a)$ to compare the fabric of undisturbed, moist tamped and slurry gold tailings samples 
and $(b)$ to investigate the effect of preparation method on the behaviour of undisturbed and reconstituted gold tailings samples at the same state. This includes consolidation, stiffness and shear behaviour. In addition, the behaviour of undisturbed samples and laboratory reconstituted samples were compared to evaluate the effectiveness of the reconstitution methods in replicating the in situ behaviour of gold tailings.

\section{EXPERIMENTAL METHODOLOGY}

To ensure consistency in the particle mineralogy, all gold tailings tested were collected from ERPM Dam 4 in Johannesburg, South Africa. As the dam has been decommissioned for approximately 10 years, access to the pond material was possible. Material was sampled near the surface from three positions, namely from the pond directly next to the penstock (pond), on the beach close to the daywall (upper beach) and further down the beach (middle beach). The positions were chosen to represent a typical range of material found in a gold tailings dam. The use of a decommissioned dam and sampling near the surface implies that oxidation may have occurred on the pyrite particles as a result of exposure to air and water (Blight \& du Preez, 1997).

Block samples were obtained from within a depth of $1 \mathrm{~m}$ by block sampling methods similar to that described by Clayton et al. (1995). In situ tailings are often highly layered, and to avoid complications due to layering, only layers with a minimum thickness of $200 \mathrm{~mm}$ were sampled for testing. Blocks were wrapped with plastic wrap, aluminium foil and a final layer of plastic wrap to prevent moisture loss. The effectiveness of this method in minimising moisture loss has been shown by Heymann \& Clayton (1999). All undisturbed samples were nevertheless tested within 1 month of sampling. Disturbed material was obtained from off-cuts of the block samples.

Laboratory reconstitution methods included both moist tamping and slurry deposition. Moist tamping is a popular laboratory preparation method owing to its simplicity and ease of obtaining a target density. There is, however, some evidence that moist tamped samples in a loose state may be susceptible to liquefaction (Casagrande, 1975; Sladen et al., 1985; Vaid et al., 1999). In contrast, it has been demonstrated that water sedimentation and slurry deposition produces samples that better replicate the in situ behaviour of sands (Oda et al., 1978; Vaid et al., 1990; Ishihara, 1993; Dyvik \& Høeg, 1999). These methods are, however, timeconsuming and susceptible to segregation when used with poorly graded materials. Furthermore, the operator has limited control over the final density (Kuerbis, 1989; Lade \& Yamamuro, 1997).

The experimental programme consists of strain-controlled undrained triaxial shear of $50 \mathrm{~mm}$ diameter undisturbed and laboratory prepared samples at the same state. The target void ratio was taken as the void ratio of the individual undisturbed samples after consolidation (and secondary consolidation). The target void ratios varied between samples, but were of the order of $1.4,1 \cdot 1$ and 0.6 for pond, middle beach $(\mathrm{MB})$ and upper beach (UB) samples respectively. Test samples were prepared to within $2 \%$ of the target void ratio. The testing programme and sample codes are summarised in Table 1. Test samples were sheared at two effective confining stresses, namely 200 and $400 \mathrm{kPa}$. Shear-200 samples were consolidated in one increment to an effective stress of $200 \mathrm{kPa}$. Shear-400 samples were consolidated by increasing the cell pressure at a rate of $10 \mathrm{~s} / \mathrm{kPa}$ to an effective confining stress of $400 \mathrm{kPa}$. A period of $24 \mathrm{~h}$ was allowed for creep to subside and pore pressure build-up was monitored for $10 \mathrm{~min}$ before shearing. If no pore pressure buildup was monitored, the test was continued with undrained shear at a constant rate of $0.1 \mathrm{~mm} / \mathrm{min}$.

One fabric sample was also prepared for each test sample. The fabric samples underwent the same triaxial processes as the test samples, but were removed prior to shear for the fabric analysis. This was done to investigate the sample fabric prior to shear. Triaxial processes for test and fabric samples are summarised in Table 2.

\section{Material tested}

Gold tailings are generally classified as sandy silt or clayey silt with little plasticity and no cohesion (McPhail \& Wagner, 1989; Vermeulen, 2001). Coarse particles are highly angular to sub-rounded while fine particles generally have a plate-like shape (Vermeulen, 2001; Chang, 2004). Mineralogy of typical gold tailings from the Witwatersrand gold reef can be summarised as containing $70-90 \%$ quartz and small amounts of muscovite, pyrophyllite and illite making up the remaining fractions (Vermeulen, 2001). The dispersed and non-dispersed grading curves of the three materials are

Table 1. Summary of experimental programme

\begin{tabular}{|c|c|c|c|c|}
\hline Material type & $\begin{array}{l}\text { Preparation } \\
\text { method }\end{array}$ & Test type & Test sample code & Fabric sample code \\
\hline Pond & $\begin{array}{l}\text { Undisturbed } \\
\text { Moist tamped } \\
\text { Slurry }\end{array}$ & $\begin{array}{l}\text { Shear } 200 \\
\text { Shear } 400 \\
\text { Shear } 200 \\
\text { Shear } 400 \\
\text { Shear } 200 \\
\text { Shear } 400\end{array}$ & $\begin{array}{l}\text { P-U-200 } \\
\text { P-U-400 } \\
\text { P-MT-200 } \\
\text { P-MT-400 } \\
\text { P-S-200 } \\
\text { P-S-400 }\end{array}$ & $\begin{array}{l}\text { P-U-200-f } \\
\text { P-U-400-f } \\
\text { P-MT-200-f } \\
\text { P-MT-400-f } \\
\text { P-S-200-f } \\
\text { P-S-400-f }\end{array}$ \\
\hline Middle beach & $\begin{array}{l}\text { Undisturbed } \\
\text { Moist tamped } \\
\text { Slurry }\end{array}$ & $\begin{array}{l}\text { Shear } 200 \\
\text { Shear } 400 \\
\text { Shear } 200 \\
\text { Shear } 400 \\
\text { Shear } 200 \\
\text { Shear } 400\end{array}$ & $\begin{array}{l}\text { MB-U-200 } \\
\text { MB-U-400 } \\
\text { MB-MT-200 } \\
\text { MB-MT-400 } \\
\text { MB-S-200 } \\
\text { MB-S-400 }\end{array}$ & $\begin{array}{l}\text { MB-U-200-f } \\
\text { MB-U-400-f } \\
\text { MB-MT-200-f } \\
\text { MB-MT-400-f } \\
\text { MB-S-200-f } \\
\text { MB-S-400-f }\end{array}$ \\
\hline Upper beach & $\begin{array}{l}\text { Undisturbed } \\
\text { Moist tamped } \\
\text { Slurry }\end{array}$ & $\begin{array}{l}\text { Shear } 200 \\
\text { Shear } 400 \\
\text { Shear } 200 \\
\text { Shear } 400 \\
\text { Shear } 200 \\
\text { Shear } 400\end{array}$ & $\begin{array}{l}\text { UB-U-200 } \\
\text { UB-U-400 } \\
\text { UB-MT-200 } \\
\text { UB-MT-400 } \\
\text { UB-S-200 } \\
\text { UB-S-400 }\end{array}$ & $\begin{array}{l}\text { UB-U-200-f } \\
\text { UB-U-400-f } \\
\text { UB-MT-200-f } \\
\text { UB-MT-400-f } \\
\text { UB-S-200-f } \\
\text { UB-S-400-f }\end{array}$ \\
\hline
\end{tabular}


Table 2. Triaxial testing scheme for test and fabric samples

\begin{tabular}{l|c|c}
\hline Description & Test sample & Fabric sample \\
\hline Sample preparation & $\checkmark$ & $\checkmark$ \\
Flushing & $\checkmark$ & $\checkmark$ \\
Saturation against back pressure & $\checkmark$ & $\checkmark$ \\
Consolidation & $\checkmark$ & $\checkmark$ \\
Creep & $\checkmark$ & $\checkmark$ \\
Shear & $\checkmark$ & \\
\hline
\end{tabular}

shown in Fig. 1. The shaded area shows the typical grading of South African gold tailings as described by Blight \& Steffen (1979). Particle density and Atterberg limits of the three materials are summarised in Table 3.

\section{Laboratory sample preparation}

Laboratory preparation methods included both moist tamping and slurry deposition. Conventional moist tamping involves compaction of moist material in a split mould to the required density or void ratio (e.g. Ladd, 1974; Vaid et al., 1999). During this project it was found that pond samples could not be prepared to the target void ratio using conventional moist tamping methods. First, energy generated from manual compaction was generally insufficient to compact the material to the required void ratio. Second, the compacted samples would crack as the split mould was removed. These problems were solved by using a hydraulic system shown in Fig. 2. The system was used to compress and extrude moist tamped samples. Preparation moisture contents were 25,15 and $7 \cdot 5 \%$ for pond, $\mathrm{MB}$ and UB samples respectively. It was interesting to note that the effort
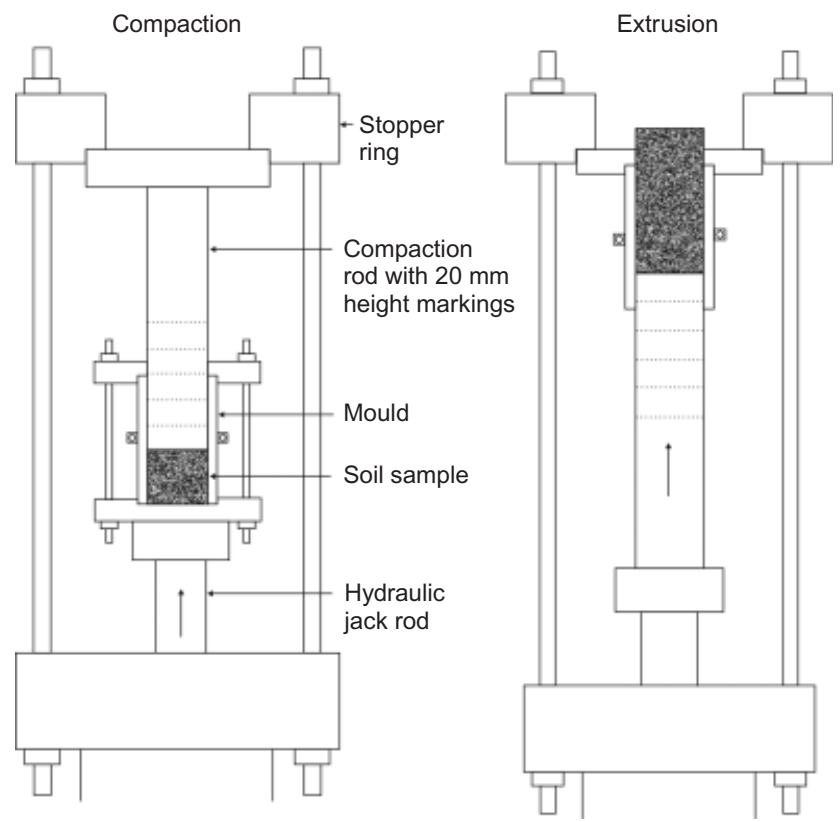

Fig. 2. Illustration of compaction and extrusion of moist tamped samples using a hydraulic jack

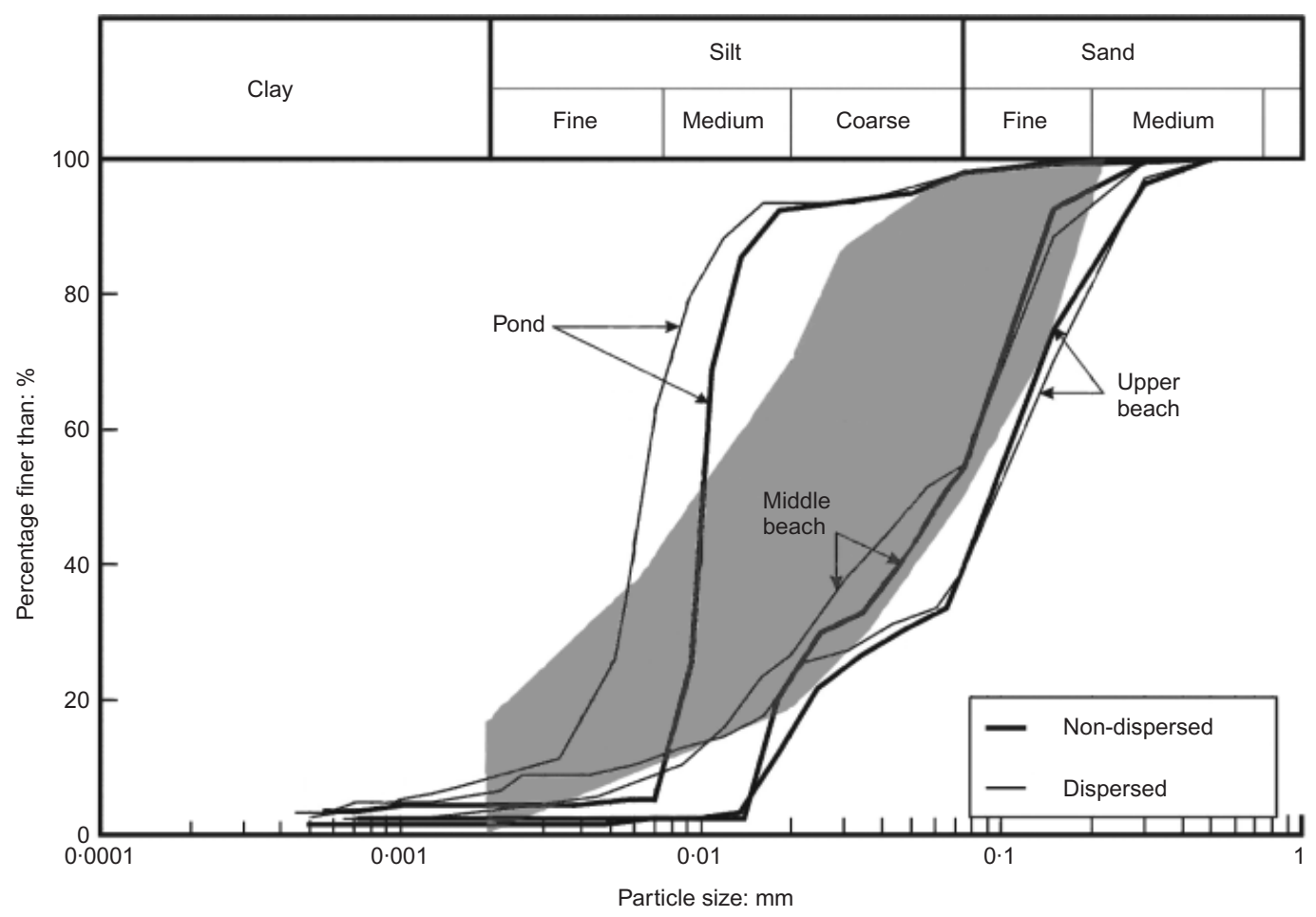

Fig. 1. Particle size distribution of gold tailings

Table 3 Summary of particle density and Atterberg limits

\begin{tabular}{l|c|c|c|c}
\hline & $G_{\mathrm{S}}$ & Liquid limit & Plastic limit & Plasticity index \\
\hline Pond & 2.75 & 51 & 39 & 12 \\
Middle beach & $2 \cdot 69$ & 30 & Non-plastic & NA \\
Upper beach & $2 \cdot 72$ & 25 & Non-plastic & NA \\
\hline
\end{tabular}


required for moist tamping (to the target void ratio) also varied. A significant force (approximately $600 \mathrm{~N}$ ) was required to compress the pond samples to the target void ratio while the UB sample required less force (approximately $150 \mathrm{~N}$ ). Little effort was required to prepare the MB samples and was easily achieved by conventional moist tamping. It is speculated that the sub-aqueous depositional environment of the in situ pond samples promotes parallel orientation of the platy particles. Moist tamping produces randomly orientated particles which require a higher energy to achieve the same void ratio. The difference in compaction effort may also be explained by comparing the limiting densities with the in situ density for the three material types, as shown in Fig. 3. Maximum and minimum density tests were performed using the vibratory table according to ASTM D 4253-93 (ASTM, 1996a) and ASTM D 4254-91 (ASTM, 1996b). These test procedures called for the soil to be tested dry. Additional tests were also conducted at higher moisture contents to investigate the bulking behaviour of the tailings. Fig. 3 shows that for the MB material the in situ void ratio was above the minimum void ratio achieved during the limiting density tests. In contrast the in situ void ratio for the UB material was the same as the minimum void ratio and the in situ void ratio of the pond material was below the minimum void ratio. As the compaction energy applied during the minimum void ratio test was the same in all three cases, it is clear that for the pond material more energy was required, for the UB material the same energy was required and for the $\mathrm{MB}$ material less compaction energy was required to achieve the in situ void ratio.

Slurry samples were prepared on the triaxial pedestal using the method similar to that described by Theron (2004) and Theron et al. (2004). The method involved deposition of the slurry at a moisture content slightly above the plastic limit in thin layers, stirring each layer after deposition. This reduces the segregation of silty slurry samples. Slurry samples for the pond material were prepared to the target void ratio with relative ease using only tap water. However, for the $\mathrm{MB}$ and UB samples this was not possible. The maximum void ratio that could be achieved for $\mathrm{MB}$ and $\mathrm{UB}$ samples using tap water was 0.8 and 0.5 respectively, which was significantly lower than the target void ratios of $1 \cdot 1$ and 0.6. Similar difficulties have been reported by Oda et al. (1978), Mao \& Fahey (1999) and Vaid \& Sivathayalan (2000) for water sedimented or slurry deposited samples. The use of flocculants and dispersants to increase the preparation void ratio of the slurry samples was investigated. Sedimentation tests were conducted using both standard laboratory dispersants (sodium hexametaphosphate) and a standard mining flocculent (Magnafloc, 919) at various concentrations to evaluate the required concentration to achieve the target void ratio. After some trial and error it was concluded that UB slurry samples could be prepared with a

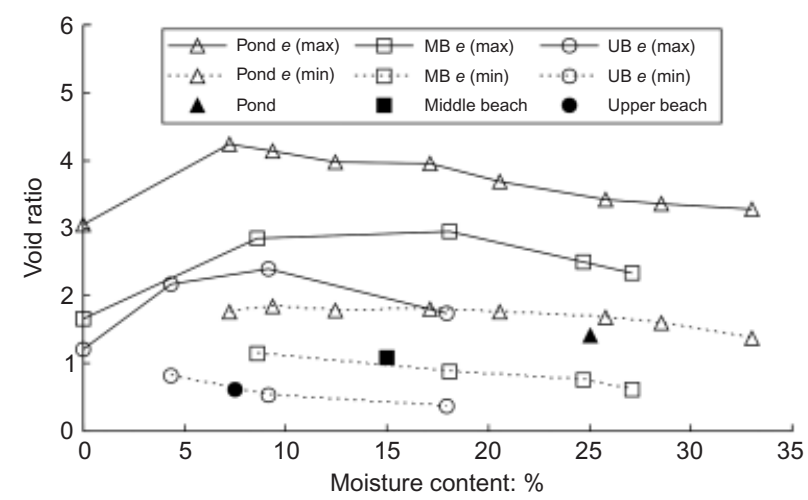

Fig. 3. Limiting density tests for gold tailings solution containing $75 \%$ tap water and $25 \%$ standard dispersant whereas MB samples were prepared using flocculent content to tap water ratio of between 1 and 3 .

Sodium-based dispersants form a cationic layer around soil particles which destroys existing aggregates and prevents further aggregation. Gold tailings particles are predominantly quartz which is a stable mineral with no weakly bonded ions and any effect from dispersants should be minimal. The effects of flocculants on the behaviour of aragonite soil have been presented by Mao \& Fahey (1999). They showed that consolidation and shear behaviour is little affected by the addition of flocculants. Olson \& Mesri (1970) conducted tests with various clays and pore water chemistry and concluded that pore fluid chemistry may affect the resulting fabric that ensues upon deposition and the fabric will in turn affect the mechanical behaviour of the clay. Changes in pore fluid chemistry and particle surface forces thus have no direct influence on the mechanical behaviour of the clay once the original fabric is established. Considerable effort was nevertheless devoted to removing the dispersant and flocculent after preparation of the sample and application of the initial cell pressure by flushing a minimum of 20 pore volumes of de-aired tap water through the sample.

\section{Image analysis}

The fabric analysis was based on SEM images of the freshly revealed surfaces of the fabric samples. Fabric samples underwent identical triaxial processes as the test samples to achieve the same void ratio as the test samples, but were not subjected to the shear phase. In addition, all SEM images were obtained with the same orientation as the triaxial samples (with the top of the image corresponding to the top of the sample). Broken fragments were mounted onto aluminium plates using carbon paint and desiccated for $24 \mathrm{~h}$ before viewing. Each sample was viewed at a magnification of 50, 200 and 1000 times.

\section{RESULTS AND DISCUSSION}

Fabric

The SEM images showed that gold tailings generally consist of three element types shown in Fig. 4

(a) large, angular or rotund, bulky particles

(b) platy particles

(c) flocks, collections of clay-sized bulky and platy particles.

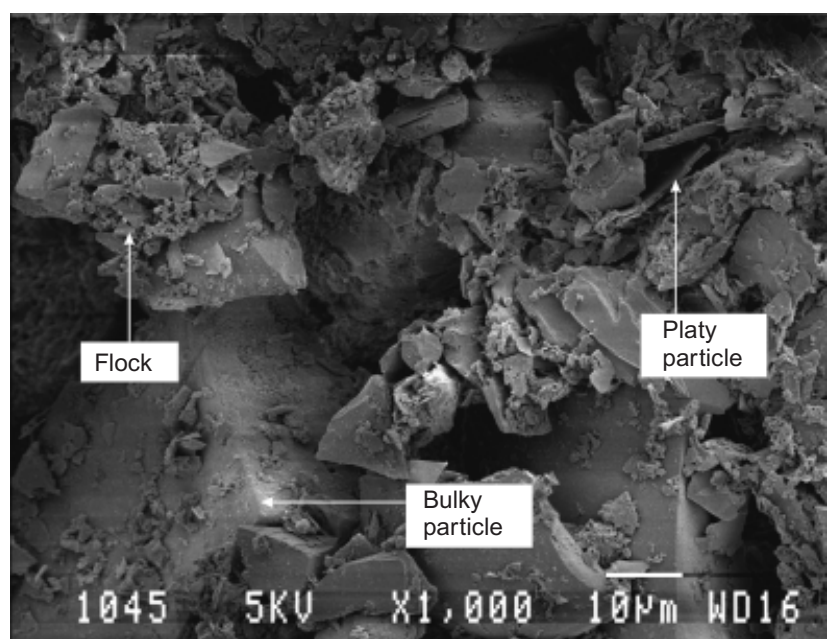

Fig. 4. Physical constitution of gold tailings at 1000 times magnification 
Similar observations have been made by Vermeulen (2001) and Chang (2004). These three elements exist in different quantities in a typical gold tailings sample. At the one extreme, pond material contains large amounts of platy particles and flocks while at the other extreme, upper beach samples contain higher quantities of coarse, bulky particles.

The SEM images of the pond samples confirmed the abundance of platy particles in the material. A general trend of the fabric of pond samples at various magnifications indicated that bulky particles were scarce and therefore not in direct contact with each other, but were dispersed in a matrix of platy particles. This is demonstrated in Fig. 5(a), which shows the typical pond fabric at 500 times magnification. From Fig. 5(b) and Fig. 5(c), it is also apparent that the middle and upper beach material was significantly coarser than the pond material, comprising larger-sized bulky particles and significantly less platy particles and flocks.

One of the main objectives of the research was visually to observe the fabric of gold tailings and compare the fabric of undisturbed and reconstituted gold tailings samples. Typical SEM images of each material/fabric types are summarised in Fig. 6. From the SEMs, it appears that the preparation method has little effect on the fabric of the pond samples. These samples consist mainly of platy particles with smallsized bulky particles $( \pm 20 \mu \mathrm{m})$ dispersed within the platy particle matrix. The fabric of the middle and upper beach samples was, however, affected by the sample preparation method. SEM images of both undisturbed and slurry samples showed a uniform fabric with platy particles dispersed around and in between the bulky particles. This fabric is termed 'uniform' fabric and is demonstrated in Fig. 7 for the UB slurry sample. In contrast, the fabric of moist tamped samples showed an abundance of flocks between bulky particles; this is termed a 'flocked' fabric and is shown in Fig. 8(a). These flocks often bridge the bulky particles, as shown in Fig. 8(b). This is similar to the fabric of natural silty clays where bulky silt particles are bridged by collections of clay particles (Yong \& Sheeran, 1973; Collins \& McGown, 1974).

\section{Particle interaction in gold tailings}

From the SEM images, some insight may be drawn regarding possible mechanical particle interaction in gold tailings. The fabric of pond samples was not affected by sample preparation method and it can be expected that the mechanical behaviour of pond samples would also be similar. Pond samples consist mainly of platy particles with bulky particles dispersed in the matrix of platy particles as shown in Fig. 9(a). This is similar to the fully dispersed or partially dispersed state proposed by Thevanayagam et al. (2002) for sand-silt mixtures. It can be expected that the behaviour of the pond samples will be dominated by the matrix of platy particles with the bulky particles providing secondary support. Idealised fabric of fine gold tailings is shown in Fig. 9(b).

SEM images indicate that middle and upper beach undisturbed and slurry samples generally show a uniform fabric with platy particles dispersed around and in between the bulky particles. Particle interaction of middle and upper beach undisturbed and slurry samples is thus a function of the amount of platy particles in the sample. The concept of threshold fines content was proposed by Thevanayagam et al. (2002) for sands, silty sands and sandy silts. Above the threshold value, sand particles are dispersed in a matrix of silt particles and behaviour will be dominated by the silt matrix with the sand particles providing secondary support. Below this threshold value, sand particles are in direct contact with each other and load is carried primarily by the

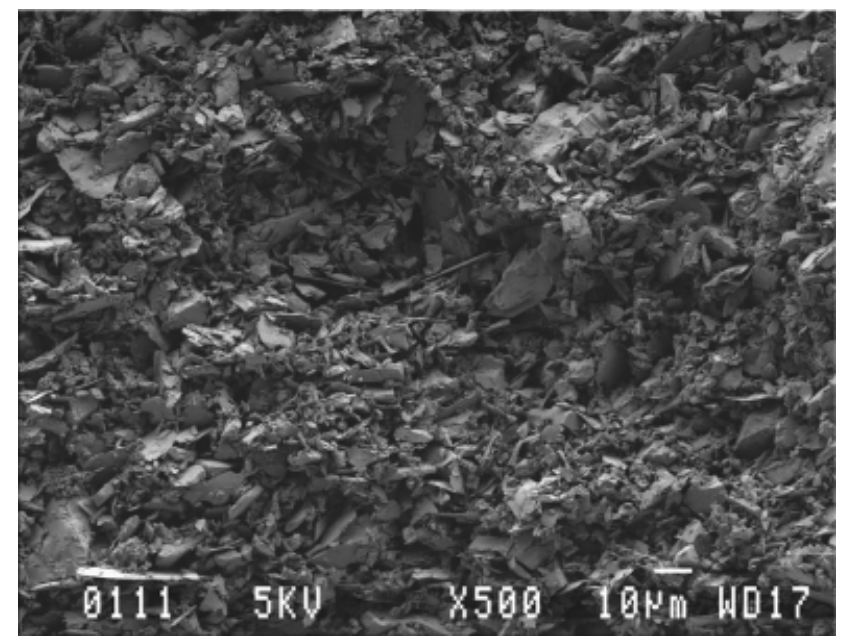

(a)

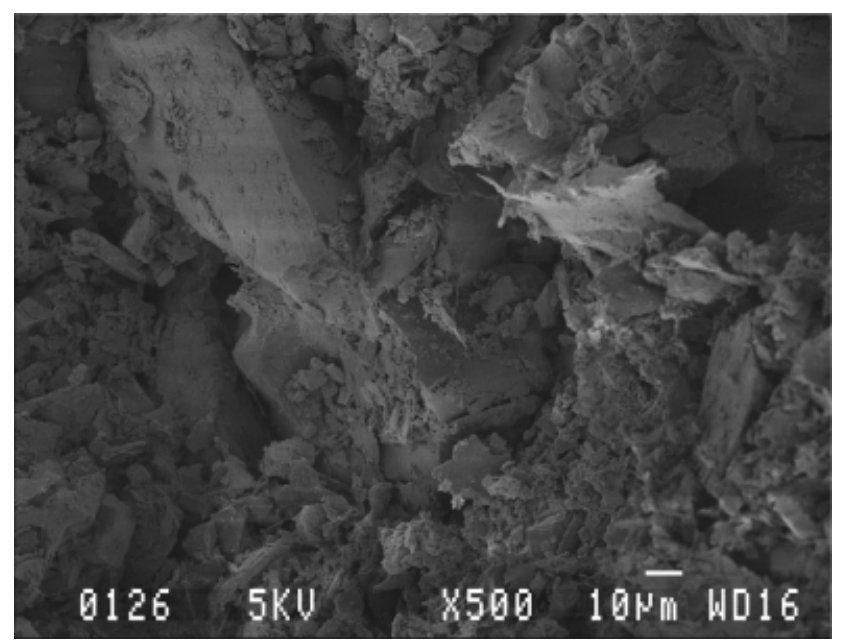

(b)

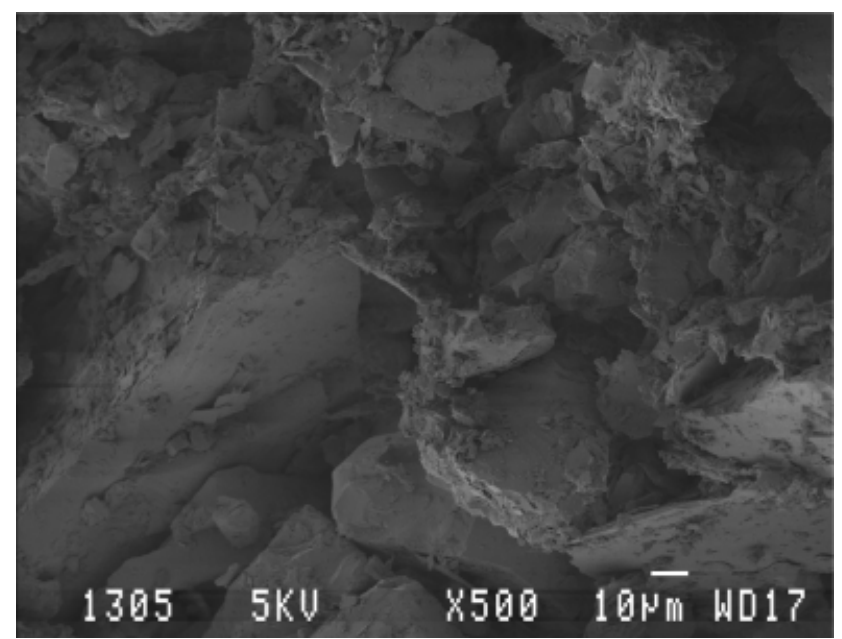

(c)

Fig. 5. Typical SEM images of (a) pond, (b) middle and (c) upper beach gold tailings material

sand skeleton with silty particles occupying the voids and providing secondary support. This threshold value for gold tailings may be significantly different to that proposed by Thevanayagam et al. (2002) for rotund sands and silts due to the plate-like shape of the fine particles.

The fabric of the undisturbed upper beach shear-200 sample is shown in Fig. 10(a), and is typical for the uniform fabric of middle and upper beach undisturbed and slurry 


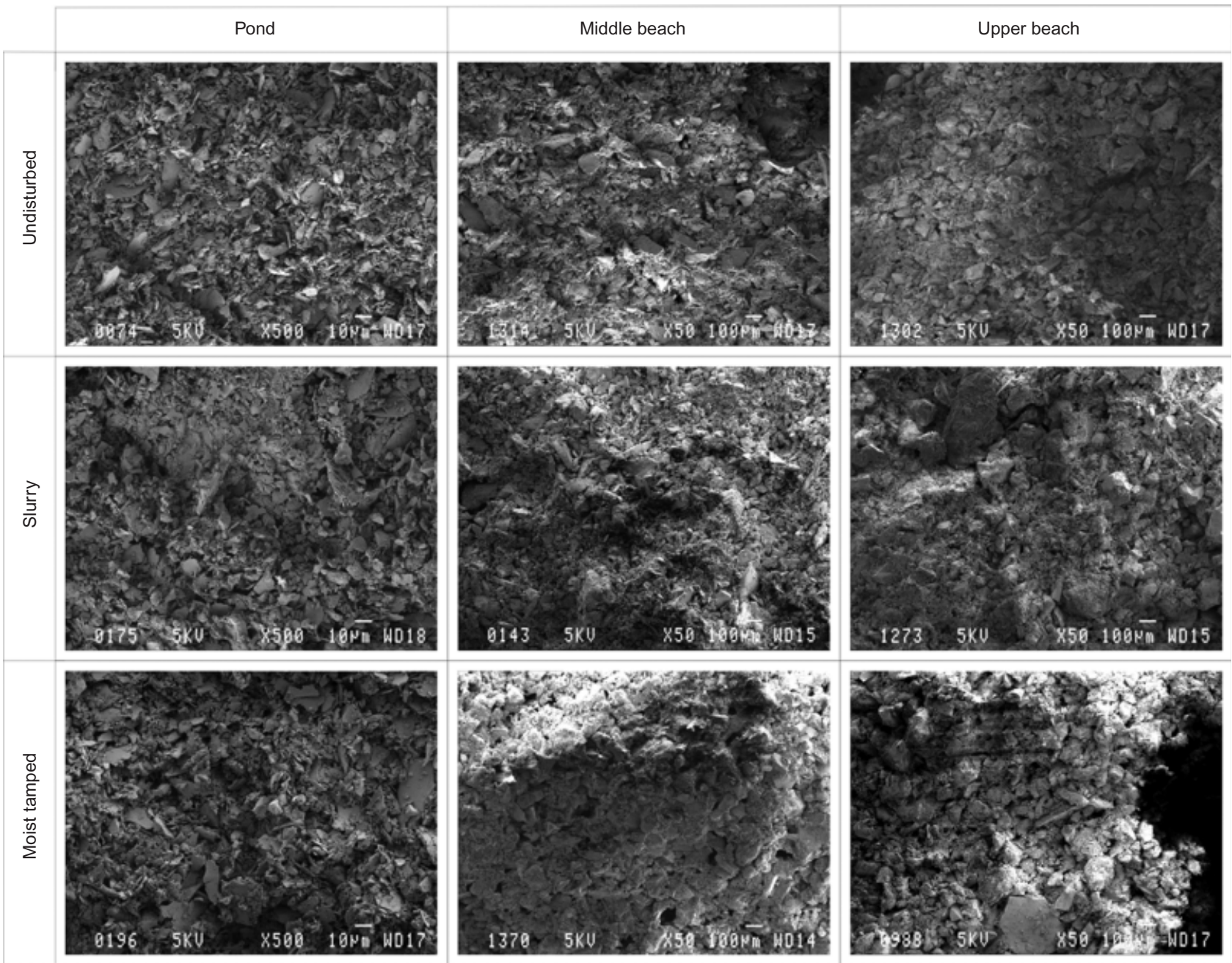

Fig. 6. Summary of undisturbed, slurry and moist tamped gold tailings fabric

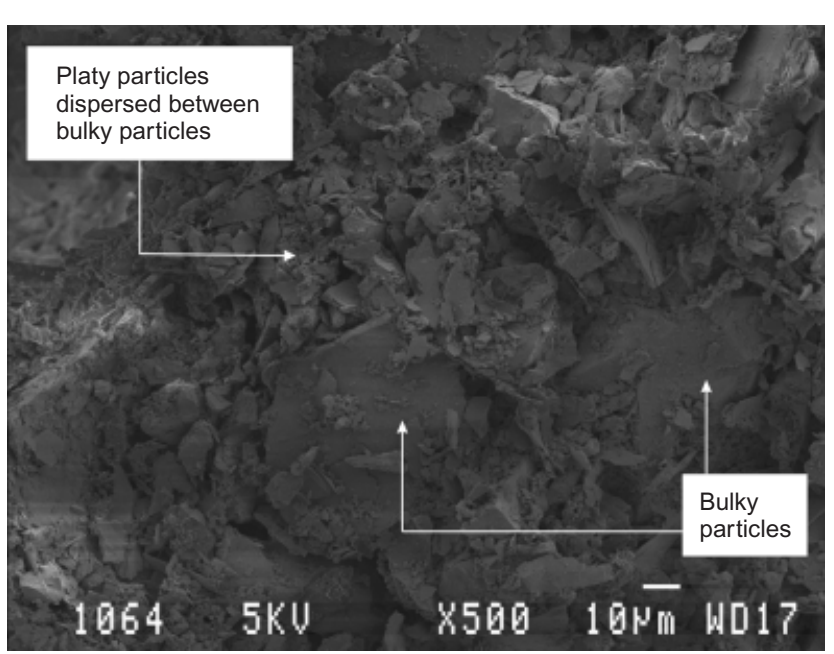

Fig. 7. Typical uniform fabric observed in upper beach slurry deposited gold tailings

samples. It can be seen from the SEM in Fig. 10(a) that there are insufficient platy particles to form a matrix as observed in the pond samples. It can thus be assumed that the bulky particles in the middle and upper beach undisturbed and slurry samples are in direct contact with each other, providing the primary support, with platy particles dispersed between the voids. The idealised fabric of uniform coarse gold tailings samples is shown in Fig. 10(b).
In Fig. 8, the SEM images show that the moist tamped middle and upper beach samples exhibit a flocked fabric with an abundance of flocks dispersed around bulky particles. The collection of platy particles into flocks results in larger pores and higher permeability and rate of consolidation compared with the uniform samples. The abundance of flocks also affects the strength and stiffness of flocked samples. The stiffness of flocks is significantly lower than bulky particles and the stiffness of the load-bearing chain of particles is a function of the bridging flocks only. This is shown in Fig. 11(a). Idealised fabric of flocked coarse gold tailings is shown in Fig. 11(b). The tendency of the flocks to deform under undrained shear also sheds stress to the pore fluid and results in a decrease in effective strength and possible strain-softening behaviour.

\section{Coefficient of consolidation}

The consolidation behaviour of soil can be expressed in terms of the coefficient of consolidation, $c_{\mathrm{V}}$ (Taylor, 1948) which is related to the permeability and compressibility of the material. Coefficient of consolidation was determined from the triaxial consolidation results for the shear-200 samples. The procedure involved raising the cell pressure by $200 \mathrm{kPa}$ under undrained conditions and then releasing the excess pore pressure. Results of the consolidation tests are summarised in Fig. 12

The pond samples with the finest grading exhibited the lowest $c_{\mathrm{V}}$ values while the UB samples with a significantly coarser grading showed the highest $c_{\mathrm{V}}$ values. The results 


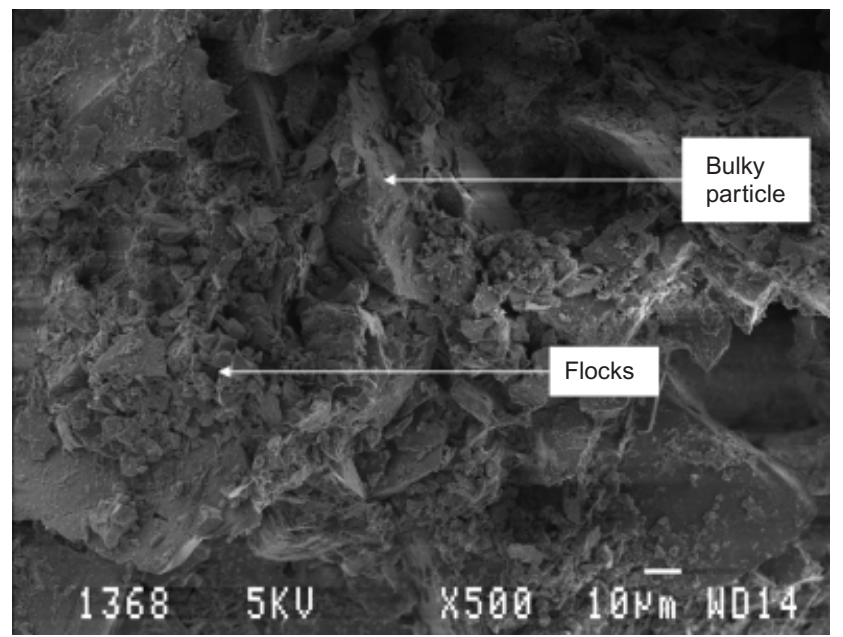

(a)

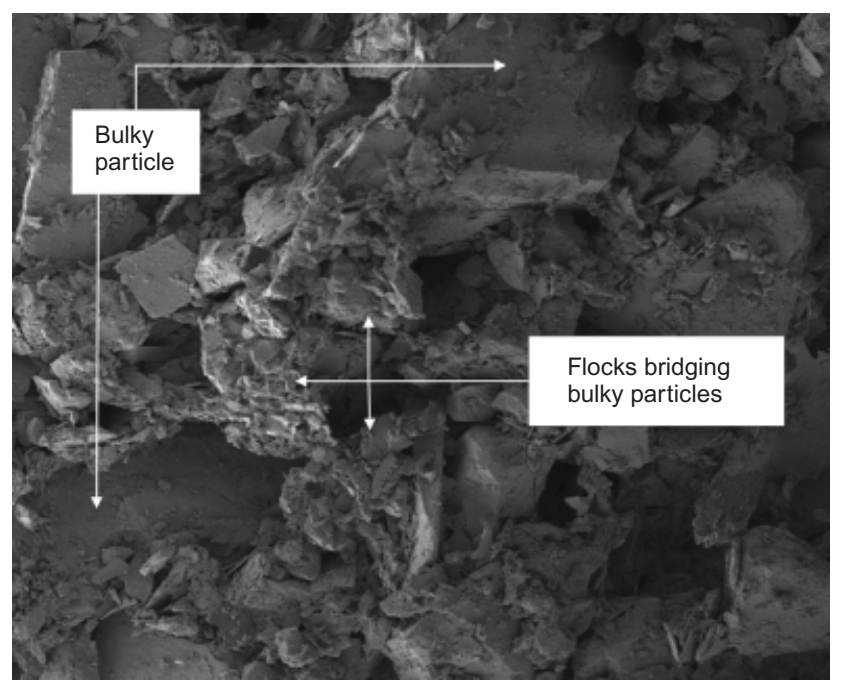

(b)

Fig. 8. Typical flocked fabric of moist tamped gold tailings showing (a) flocks around bulky particles (middle beach) and (b) flocks bridging bulky particles (upper beach)

also showed that $c_{\mathrm{V}}$ values may be significantly affected by the fabric produced by different sample preparation methods. Moist tamped samples exhibited the highest $c_{\mathrm{V}}$ values while undisturbed and slurry samples showed lower $c_{\mathrm{V}}$ values. The coefficient of consolidation of the moist tamped samples was generally 2 to 3 times that of the undisturbed and slurry samples.

\section{Young's modulus}

The Young's modulus $E$ of the shear samples was defined as the secant value at specific axial strains relative to the origin on the $q^{\prime}-\varepsilon_{\text {a }}$ graph. Axial strain was measured in the middle $50 \mathrm{~mm}$ of the sample using two local linear variable differential transformers (LVDTs).

The results from the shear samples showed that there is significant amount of scatter below $0.002 \%$ axial strain, indicating that the LVDTs used may not be capable of accurately identifying the linear plateau for strains less than $0.002 \%$ (Heymann, 1998). The small strain stiffness for gold tailings can, nevertheless, be estimated. It was decided that the small strain stiffness would be taken as the average value of the stiffness values in the range $0 \cdot 0001-0 \cdot 001 \%$ axial strain. An example for P-U-200 is shown in Fig. 13. The results indicate that the fabric may have a significant influence on the small

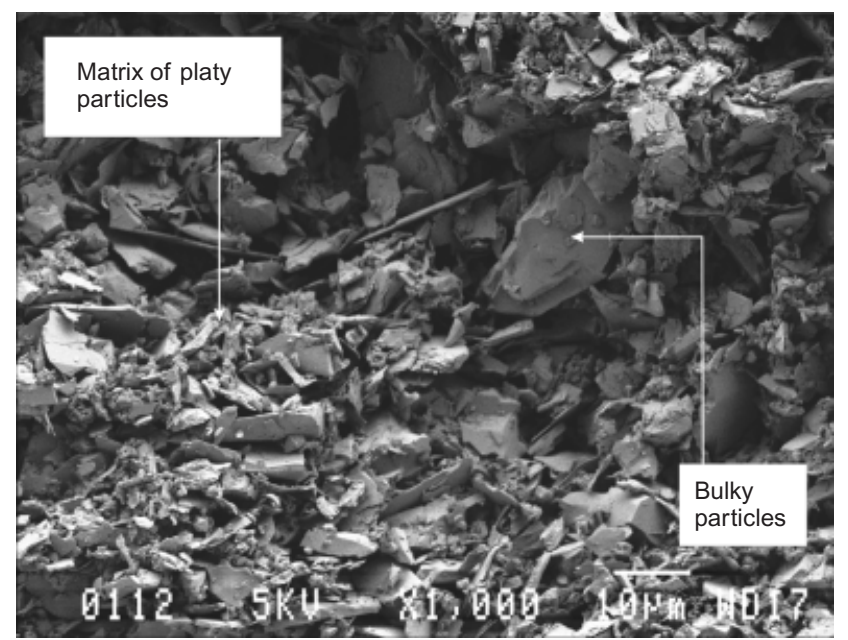

(a)

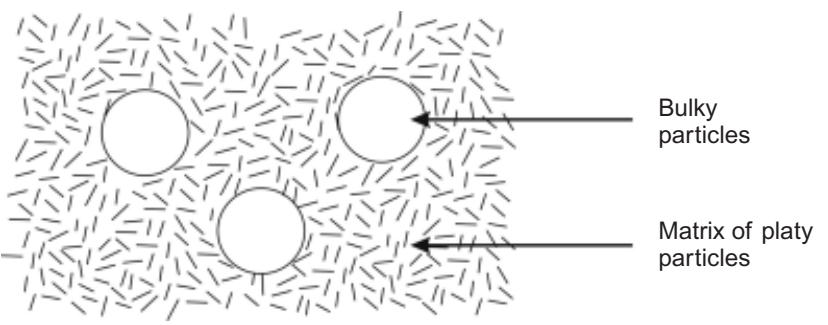

(b)

Fig. 9. Fabric of pond gold tailings in (a) SEM image, (b) idealised fabric

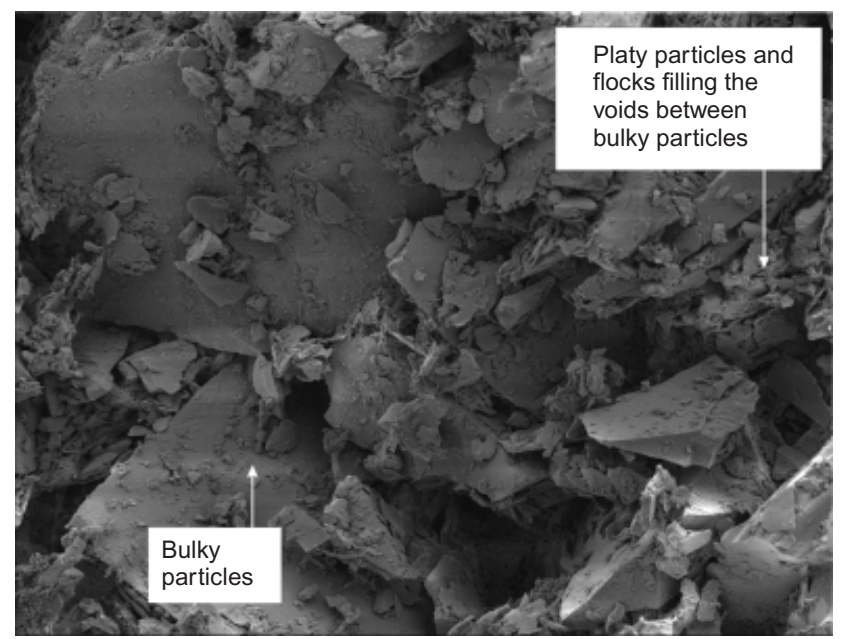

(a)

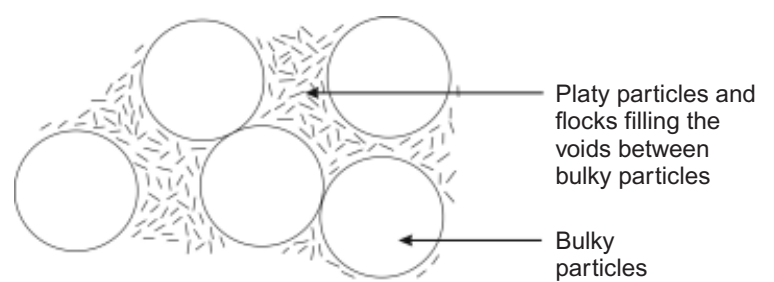

(b)

Fig. 10. Fabric of uniform middle and upper beach gold tailings in (a) SEM image, (b) idealised fabric

strain stiffness of gold tailings. Slurry samples exhibited $E_{\max }$ values fairly close to those of the undisturbed counterparts while moist tamped samples generally showed lower $E_{\max }$ values in comparison to the undisturbed samples. The use of 


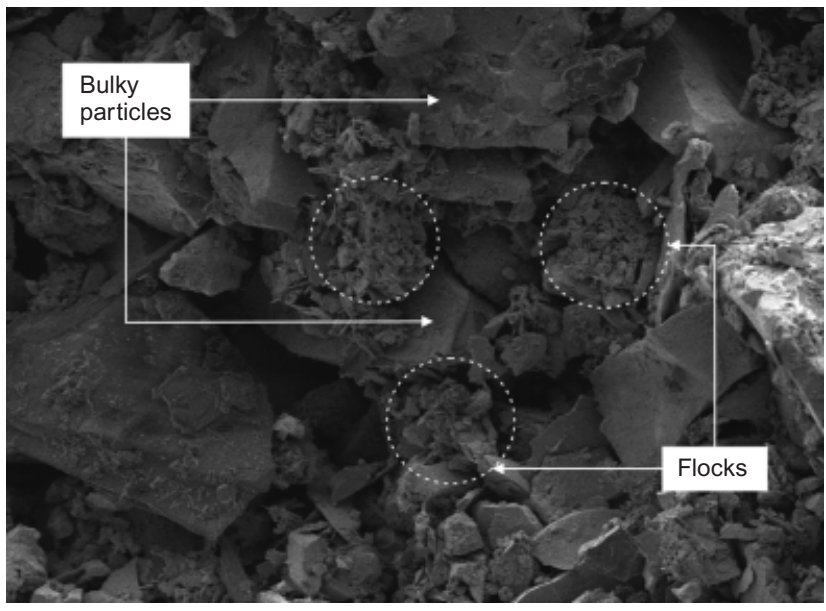

(a)

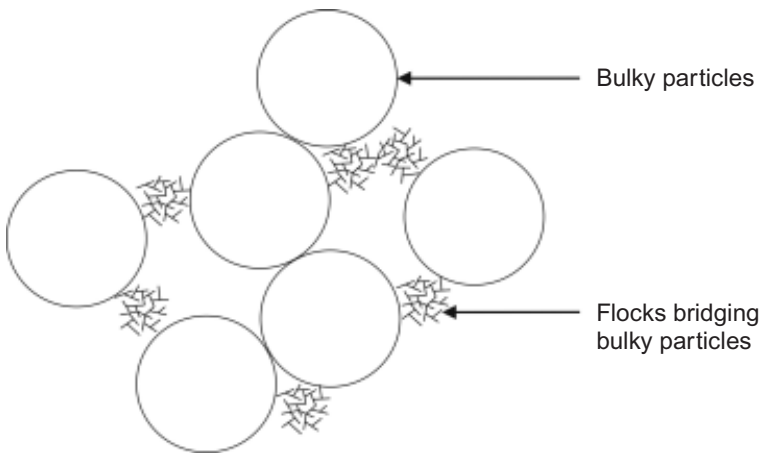

(b)

Fig. 11. Fabric of flocked middle and upper beach gold tailings in (a) SEM image, (b) idealised fabric

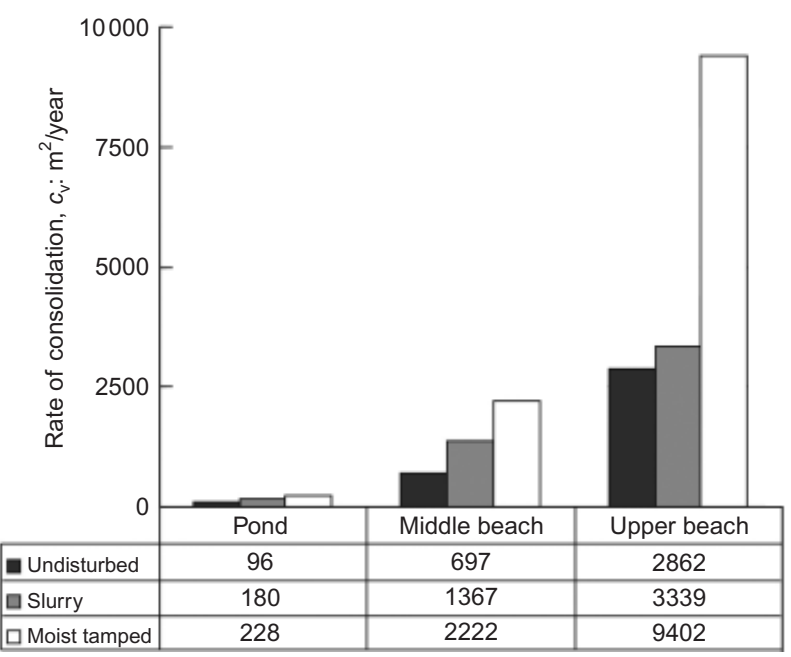

Fig. 12. Coefficient of consolidation of gold tailings

moist tamping, on average, underestimated $E_{\max }$ values by $14 \%$ and up to $43 \%$ in one case, whereas the use of slurry deposition may slightly overpredict $E_{\max }$ values in some cases. $E_{\max }$ values for gold tailings are summarised in Fig. 14.

The range of stiffness degradation curves (normalised against $\left.E_{\max }\right)$ of gold tailings are shown in Fig. 15. It should be noted that due to the definition of $E_{\max }$ (as indicated in Fig. 13), normalised $E$ values may not be exactly unity. The stiffness degradation curves shown in Fig. 15 indicate that the reduction in stiffness may be as high as $40 \%$ at $0.01 \%$ axial strain and between 50 and $80 \%$ at $0 \cdot 1 \%$ axial strain.

Small strain stiffness is often normalised against initial

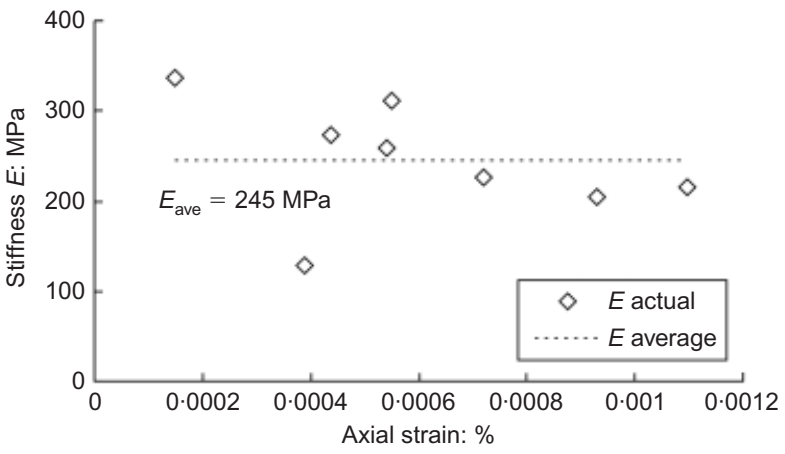

Fig. 13. Example of small strain stiffness estimation (P-U-200)

confining stress $p_{0}^{\prime}$. The normalised small strain stiffness (against initial confining stress, $p_{\mathrm{o}}^{\prime}$ ) of gold tailings was found to be in the range $1000-1500$ with an average of 1130

\section{Shear behaviour}

The stress paths (in $p^{\prime}-q^{\prime}$ space) for all shear samples are shown in Fig. 16. The slope of the critical state line in $p^{\prime}-$ $q^{\prime}$ space $(M)$ and friction angle $\phi^{\prime}$ are summarised in Table 4. It is interesting to note that the friction angles $\phi^{\prime}$ for all three material types were similar, despite different particle grading and shape. This is in agreement with the conclusions from other research (e.g. Vermeulen, 2001). The shear results also showed that the fabric had no effect on the friction angle or critical state parameter $M$. This is in agreement with the findings of Zlatovic \& Ishihara (1997), who concluded that the fabric has no effect on the strength characteristics of soils.

Static liquefaction is associated with strongly contractive behaviour coupled with strain softening. Complete liquefaction occurs when the deviatoric stress and mean effective stress approaches zero. The static liquefaction potential of sands and silty sands has been shown to be significantly affected by the sample preparation method (e.g. Chillarige et al., 1997; Zlatovic \& Ishihara, 1997; Dyvik \& Høeg, 1999; Vaid et al. 1999), and similar effects was observed in these gold tailings.

The stress paths shown in Fig. 16 indicate that the gold tailings did not show pure dilative behaviour with effective stress $p^{\prime}$ increasing throughout shear. Samples either contract and then dilate (phase transfer dilation) to failure or contract and strain soften to failure. Complete static liquefaction was not observed.

All pond samples exhibited similar phase transfer dilation. As shown by the SEM images, pond samples exhibit similar fabric irrespective of the sample preparation method and it is thus not surprising that all pond samples demonstrate similar shear behaviour. For middle and upper beach, undisturbed and slurry samples exhibited phase transfer dilation. Some MB and UB moist tamped samples, however, showed strain softening behaviour to the critical state without complete liquefaction. As seen in the SEMs, moist tamped samples contain large quantities of flocks compared to the undisturbed and slurry counterparts. The deformation or collapse of flocks during undrained shear results in elevated pore water pressure accompanied by reduction of the effective strength. The implication of this is best shown by the stress paths of MB shear-200 samples in Fig. 17. The use of moist tamped samples for design may in some cases introduce unnecessary conservatism.

\section{The critical state}

The critical state defines the ultimate conditions of failure where shear distortions occur without further changes in 




Fig. 14. Small strain stiffness, $E_{\max }$, of gold tailings

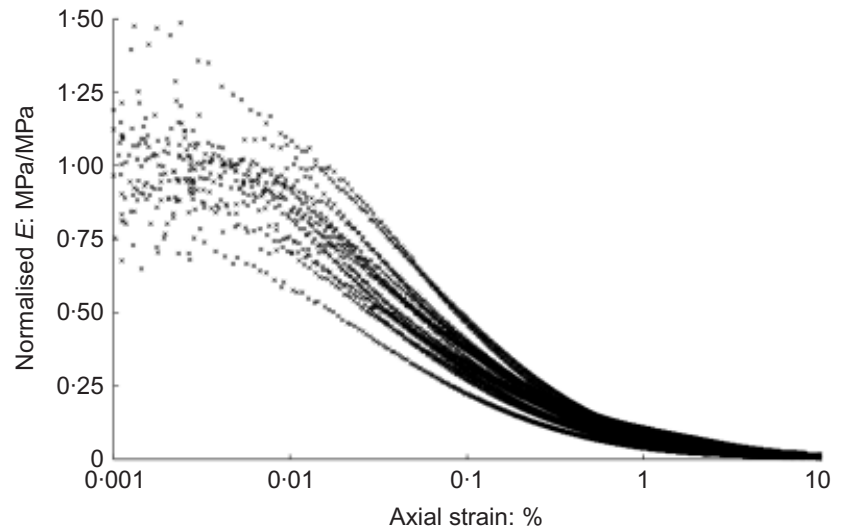

Fig. 15. Stiffness degradation of gold tailings (normalised against $E_{\max }$ )

mean normal stress, deviatoric stress or specific volume (Schofield \& Wroth, 1968; Atkinson \& Bransby, 1978). The shearing process was terminated when either a critical state was reached or when further shearing could damage the locally mounted LVDTs. This implies that for a few samples, the critical state may not have been reached at the end of shearing. Stress-strain curves indicate that these samples were generally close to the critical state and some conclusions can thus be made regarding the position and uniqueness of the critical state line.

The stress paths (in $p^{\prime}-q^{\prime}$ space) indicate that the samples reach a unique stress ratio $M$, but different values of deviatoric stress $q^{\prime}$ and confining stress $p^{\prime}$ at critical state. This implies that the position of the critical state line depends on the fabric of the gold tailings material. Similar conclusions have been made for sands, silty sands and tailings (Dyvik \& Høeg, 1999; Vaid et al., 1999; Wood \& Yamamuro, 1999).

\section{CONCLUSIONS}

An experimental programme was undertaken to investigate the effect of laboratory sample preparation method on the fabric and behaviour of gold tailings and to comment on the effectiveness of the laboratory sample preparation to reproduce the in situ fabric and behaviour. The conclusions are summarised as follows.

(a) SEM images showed that the fabrics of the coarse MB and UB samples were significantly affected by the preparation method. Slurry deposition produced a uniform fabric similar to that of the undisturbed samples while moist tamping produced a flocked fabric with collections of platy particles, or flocks between bulky particles. The sample preparation method had, however, little effect on the fabric of pond samples consisting largely of fine platy particles.

(b) Coefficient of consolidation was significantly affected by the sample preparation method. The $c_{\mathrm{V}}$ values for moist tamped samples were generally 2 to 3 times higher than that of the undisturbed and slurry counterparts. The collection of platy particles into flocks may have resulted in larger pores and thus higher coefficient of consolidation in comparison with the more uniform undisturbed and slurry samples.

(c) The small strain stiffness of moist tamped samples was on average $14 \%$ lower than the undisturbed samples, but the reduction in stiffness may be as high as $43 \%$. The difference may be affected by particle properties or preparation energy. Slurry samples exhibited similar small strain stiffness as the undisturbed samples.

(d) Normalised small strain stiffness (against mean effective stress, $\left.p_{0}^{\prime}\right)$ was in the range 1000-1500.

(e) Reductions in stiffness $E$ from the initial stiffness $E_{\max }$ may be as high as 40 and $80 \%$ at strains of 0.01 and $0 \cdot 1 \%$ respectively.

( $f$ ) Friction angle $\phi^{\prime}$ or the stress ratio at critical state, $M$, was not significantly affected by the gradation or fabric of the gold tailings.

( $g$ ) The static liquefaction behaviour of gold tailings was significantly affected by the preparation method and fabric. Middle and upper beach undisturbed and slurry samples exhibited contractive behaviour followed by dilation while some moist tamped samples contracted and strain softened during shear. Reduction in the peak strength was in the range of $25 \%$, but may be as high as $45 \%$. 
196

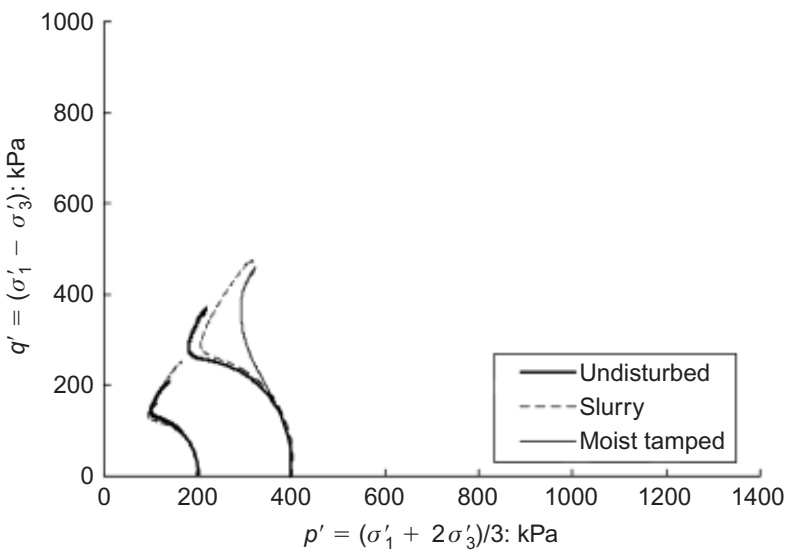

(a)

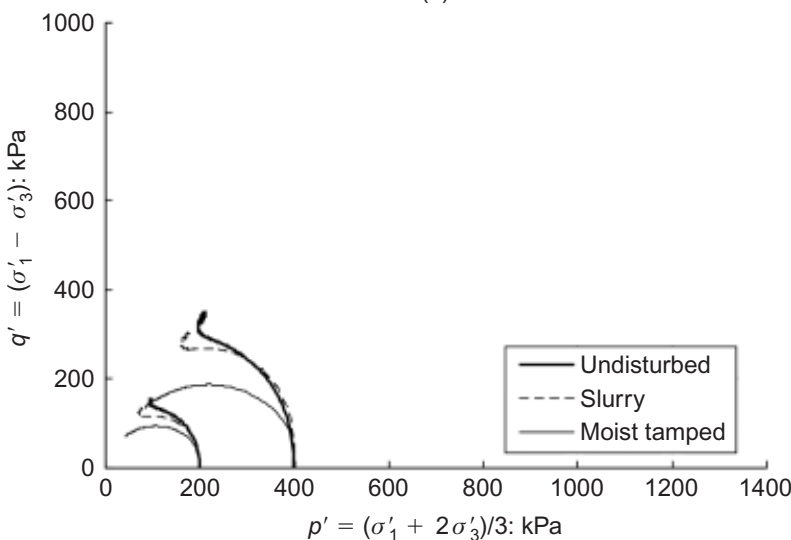

(b)

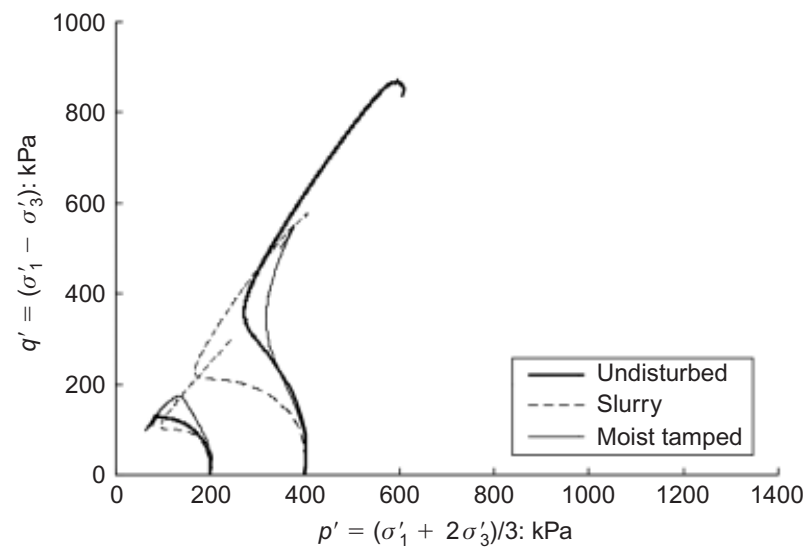

(c)

Fig. 16. Stress paths in $p^{\prime}-q^{\prime}$ space of (a) pond, (b) middle beach and (c) upper beach gold tailings

(h) The critical state line for gold tailings is non-unique and depends on the fabric. Gold tailings reach different values of $p^{\prime}$ and $q^{\prime}$, but tend to a unique stress ratio, $M$, at the critical state.

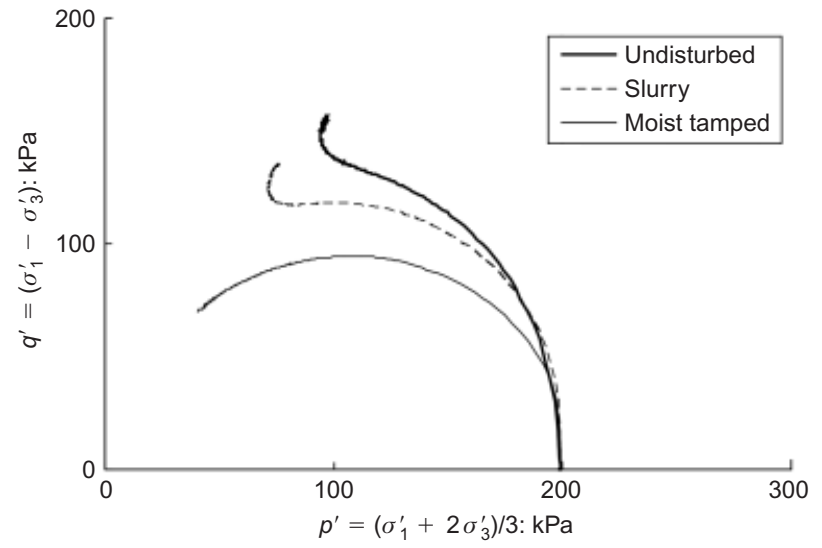

Fig. 17. Stress paths of middle beach shear-200 samples

Based on the results of this paper, it can be seen that neither moist tamping nor slurry deposition fully replicates the behaviour of the undisturbed gold tailings samples. Judgement on the appropriate sample preparation method depends on the material behaviour or property under investigation.

\section{ACKNOWLEDGEMENTS}

The authors would like to thank Fraser Alexander for permission to access and sample the material from the ERPM tailings dams. Assistance from $\mathrm{Mr}$ Alan Hall and $\mathrm{Mr}$ Andre Botha from the Laboratory for Microscopy and Microanalysis at the University of Pretoria is greatly appreciated.

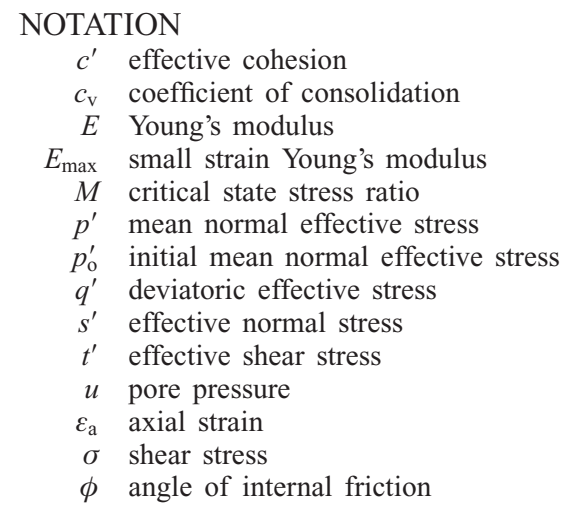

\section{REFERENCES}

ASTM (1996a). Test method for maximum index density and unit weight of soils using vibratory table, D4253-93. Annual Book of ASTM Standards. West Conshohocken, PA: American Society for Testing and Materials.

ASTM (1996b). Standard test method for minimum index density and unit weight of soils and calculation of relative

Table 4. Critical state parameter $M$ and friction angles for gold tailings

\begin{tabular}{l|c|c|c|c|c|c}
\hline \multirow{2}{*}{} & \multicolumn{2}{|c|}{ Pond } & \multicolumn{2}{c|}{ Middle beach } & \multicolumn{2}{c}{ Upper beach } \\
\cline { 2 - 7 } & $M$ & $\phi^{\prime}$ & $M$ & $\phi^{\prime}$ & $M$ & $\phi^{\prime}$ \\
\hline Undisturbed & 1.69 & 32.7 & 1.73 & 32.9 & 1.61 & 31.2 \\
Moist tamped & 1.51 & 30.3 & 1.73 & NA & 1.53 & 30.7 \\
Slurry & 1.68 & 31.6 & 1.87 & 34.3 & 1.56 & 31.4 \\
Average & 1.62 & 31.5 & 1.78 & 33.6 & 1.56 & 31.1 \\
\hline
\end{tabular}


density, D4254-91. Annual Book of ASTM Standards. West Conshohocken, PA: American Society for Testing and Materials.

Atkinson, J. H. \& Bransby, P. L. (1978). The mechanics of soils: an introduction to critical state soil mechanics. London: McGrawHill.

Blight, G. E. \& du Preez, J. (1997). The escape of salt pollution from decommissioned gold residue deposits in South Africa. J. South African Inst. Mining and Metallurgy, July/August, 201-204.

Blight, G. E. \& Steffen, K. H. (1979). Geotechnics of gold mine waste disposal. Current geotechnical practice in mine waste disposal, pp. 1-53. New York: ASCE.

Casagrande, A. (1975). Liquefaction and cyclic deformation of sands: a critical review. Proceedings of the Pan-American conference on soil mechanics and foundation engineering, Buenos Aires, Vol. 5, pp. 79-133.

Chang, H. N. (2004). The relationship between shear wave velocity and void ratio of gold tailings. MEng thesis, University of Pretoria, Pretoria.

Chillarige, A. R. V., Morgenstern, N. R., Robertson, P. K. \& Christian, H. (1997). Seabed instability due to flow liquefaction in the Fraser River delta. Can. Geotech. J. 34, No. 4, 520-533.

Clayton, C. R. I., Matthews, C. \& Simons, N. E. (1995). Site investigation, 2nd edn. Oxford: Blackwell Science.

Collins, K. \& McGown, A. (1974). The form and function of microfabric features in a variety of natural soils. Géotechnique 24, No. 2, 223-254, doi: 10.1680/geot.1974.24.2.223.

Dyvik, R. \& Høeg, K. (1999). Comparison of tests on undisturbed and reconstituted silt and silty sand. In Physics and mechanics of soil liquefaction (eds P. V. Lade and J. A. Yamamuro), pp. 159-168. Rotterdam: Balkema.

Høeg, K., Dyvik, R. \& Sandbaekken, G. (2000). Strength of undisturbed versus reconstituted silt and silty sand specimens. J. Geotech. Geoenviron. Engng 126, No. 7, 606-616.

Heymann, G. (1998). The stiffness of soils and weak rocks at very small strains. PhD thesis, University of Surrey, Surrey.

Heymann, G. \& Clayton, C. R. I. (1999). Block sampling of soils: some practical considerations. In Geotechnics of developing Africa (eds G. R. Wardle, G. E. Blight and A. B. Fourie), pp. 331-339. Rotterdam: Balkema.

Ishihara, K. (1993). Liquefaction and flow failure during earthquakes. Géotechnique 43, No. 3, 351-415, doi: 10.1680/geot. 1993.43.3.351.

Kuerbis, R. (1989). The drained loading response of sands. MSc thesis, University of British Columbia.

Kuerbis, R. \& Vaid, Y. P. (1988). Sand sample preparation - the slurry deposition method. Soils Found. 28, No. 4, 107-118.

Ladd, R. S. (1974). Specimen preparation and liquefaction of sands. ASCE J. Geotech. Engng Div. 100, No. GT10, 1180-1184.

Lade, P. V. \& Yamamuro, J. A. (1997). The effect of nonplastic fines on static liquefaction of sands. Can. Geotech. J. 34, No. 3, 918-928.

Lambe, T. W. \& Whitman, R. V. (1969). Soil mechanics. New York: Wiley.

Mao, X. \& Fahey, M (1999). A method of reconstituting aragonite soil using a synthetic flocculant. Géotechnique 49, No. 1, 15-32, doi: $10.1680 /$ geot.1999.49.1.15.

McPhail, G. I. \& Wagner, J. C. (1989). Disposal of residues. In The extractive metallurgy of gold in South Africa, vol. 2 (ed. G. G. Stanley), pp. 655-707. Johannesburg: The Chamber of Mines of South Africa.

Mitchell, J. K. (1976). Fundamentals of soil behaviour. New York: Wiley.

Mulilis, J. P., Seed, H. B., Chan, C. K., Mitchell, J. K. \& Arulanandan, K. (1977). Effects of sample preparation on sand liquefaction. ASCE J. Geotech. Engng Div. 103, No. GT2, 91-108.

Oda, M. (1972). Deformation mechanism of sands in triaxial compression tests. Soils Found. 12, No. 4, 45-63.

Oda, M., Koishikawa, I. \& Higuchi, T. (1978). Experimental study of anisotropic shear strength of sands by plane strain test. Soils Found. 18, No. 1, 25-38.

Olson, R. E. \& Mesri, G. (1970). Mechanisms controlling compressibility of clays. J. Soil Mech. Found. Div. 96, No. SM6, 18631878 .

Schofield, A. N. \& Wroth, C. P. (1968). Critical state soil mechanics. London: McGraw-Hill.

Sladen, J. A., D'Hollander, R. D. \& Krahn, J. (1985). The liquefaction of sands: a collapse surface approach. Can. Geotech. J. 22, No. 4, 564-578.

Taylor, D. W. (1948). Fundamentals of soil mechanics. New York: Wiley.

Theron, M. (2004). The influence of fine platy particles on the behaviour of a rotund sand. $\mathrm{PhD}$ thesis, University of Southampton, Southampton.

Theron, M., Heymann, G. \& Clayton, C. R. I. (2004). The small strain stiffness of gold tailings. Geotechnical and geophysical site characterization, vol. 1 (eds A. V. Dafonseca and P. W. Mayne), pp. 575-580. Rotterdam: Millpress.

Thevanayagam, S., Shenthan, T., Mohan, S. \& Liang, J. (2002). Undrained fragility of clean sands, silty sands and sandy silts. J. Geotech. Geoenviron. Engng 128, No. 10, 849-859.

Vaid, Y. P. \& Sivathayalan, S. (2000). Fundamental factors affecting liquefaction susceptibility of sands. Can. Geotech. J. 37, No. 3, 592-606.

Vaid, Y. P., Chung, E. K. F. \& Kuerbis, R. H. (1990). Stress path and steady state. Can. Geotech. J. 27, No. 1, 1-7.

Vaid, Y. P., Sivathayalan, S. \& Stedman, D. (1999). Influence of specimen reconstituting method on the undrained response of sands. Geotech. Testing J. 22, No. 3, 187-195.

Vermeulen, N. J. (2001). The composition and state of gold tailings. $\mathrm{PhD}$ thesis, University of Pretoria, Pretoria.

Wood, F. M. (1999). Influence of specimen reconstitution method on the undrained response and microstructure of silty sands. MSc thesis, Clarkson University.

Wood, F. M. \& Yamamuro, J. A. (1999). The effect of depositional method on the liquefaction behaviour of silty sands. Proc. 13th ASCE Engng Mech. Conf., Baltimore, MD, USA (CD-ROM).

Yamamuro, J. A. \& Lade, P. V. (1997). Static liquefaction of very loose sands. Can. Geotech. J. 34, No. 3, 905-917.

Yong, R. N. \& Sheeran, D. E. (1973). Fabric unit interaction and soil behaviour. Proceedings of the international symposium on soil structure, Gothenburg, pp. 176-183.

Zlatovic, S. \& Ishihara, K. (1997). Normalized behavior of very loose non-plastic soils: effects of fabric. Soils Found. 37, No. 4, $47-56$. 